Article

\title{
Subtle Changes or Dramatic Perceptions of Air Pollution in Sydney during COVID-19
}

\author{
Peter Brimblecombe ${ }^{1, *(1)}$ and Yonghang Lai ${ }^{2}$ \\ 1 Department of Marine Environment and Engineering, National Sun Yat-Sen University, \\ Kaohsiung 80424, Taiwan \\ 2 School of Energy and Environment, City University of Hong Kong, Hong Kong, China; \\ yonghalai2-c@my.cityu.edu.hk \\ * Correspondence: p.brimblecombe@uea.ac.uk
}

Citation: Brimblecombe, P.; Lai, Y. Subtle Changes or Dramatic Perceptions of Air Pollution in Sydney during COVID-19.

Environments 2021, 8, 2. https://doi. org/10.3390/environments8010002

Received: 19 November 2020 Accepted: 29 December 2020 Published: 1 January 2021

Publisher's Note: MDPI stays neutral with regard to jurisdictional clai$\mathrm{ms}$ in published maps and institutional affiliations.

Copyright: $\odot 2021$ by the authors. Licensee MDPI, Basel, Switzerland. This article is an open access article distributed under the terms and conditions of the Creative Commons Attribution (CC BY) license (https:// creativecommons.org/licenses/by/ $4.0 /)$.

\begin{abstract}
The COVID-19 pandemic made it critical to limit the spread of the disease by enforcing human isolation, restricting travel and reducing social activities. Dramatic improvements to air quality, especially $\mathrm{NO}_{2}$, have often characterised places under COVID-19 restrictions. Air pollution measurements in Sydney in April 2019 and during the lockdown period in April 2020 show reduced daily averaged $\mathrm{NO}_{2}$ concentrations: $8.52 \pm 1.92$ and $7.85 \pm 2.92 \mathrm{ppb}$, though not significantly so $\left(p_{1} \sim 0.15\right)$ and $\mathrm{PM}_{2.5} 8.91 \pm 4.94$ and $7.95 \pm 2.64 \mu \mathrm{g} \mathrm{m}^{-3}$, again a non-significant difference $\left(p_{1} \sim 0.18\right)$. Satellite imagery suggests changes that parallel those at ground level, but the column densities averaged over space and time, in false-colour, are more dramatic. Changed human mobility could be traced in increasing times spent at home, assessed from Google Mobility Reports and mirrored in decreased traffic flow on a major road, suggesting compliance with the restrictions. Electricity demand for the State of New South Wales was low under lockdown in early April 2020, but it recovered rapidly. Analysis of the uses of search terms: bushfires, air quality, haze and air pollution using Google Trends showed strong links between bushfires and pollution-related terms. The smoke from bushfires in late 2019 may well have added to the general impression of improved air quality during lockdown, despite only modest changes in the ground level measurements. This gives hints that successful regulation of air quality requires maintaining a delicate balance between our social perceptions and the physical reality.
\end{abstract}

Keywords: Australia; bushfires; lockdown; public perception; social media; traffic; visibility

\section{Introduction}

Dramatic improvements to air quality have often characterised places under COVID19 lockdowns. The coronavirus (often called SARS-CoV-2) was identified in December 2019 and the contagious nature of the virus was established shortly after [1]. It became critical to limit epidemic spread, so there was a growing need to enforce human isolation, restrict travel and reduce social activity [1]. The megacity of Wuhan was at the epicentre of the outbreak and locked down on 23 January 2020, with other nearby cities nearby, namely, Huanggang, and Ezhou and Huangshi, following soon after [2]. Wuhan remained under lockdown until 8 April, though some cities of Hubei province opened earlier. In Beijing, a lockdown was not enforced, but following a two-day extension to the Chinese New Year holiday, there were pressures on the population to reduce activity and these more modest restrictions were seen widely across China [1]. Gradually, such responses spread around the globe. Australia was no different, with the Government declaring a human biosecurity emergency on 18 March 2020. The New South Wales (NSW) government increasingly strengthened restrictions in an extraordinary set of emergency orders through late March: "In what must be the most far-reaching legal instruction in NSW's history, the Minister for Health, Brad Hazzard, has now directed every person within the state to remain in their residence" [3]. 
Limiting travel and human activity, during lockdown, reduced pollutant emissions. Concentration reductions, especially of nitrogen dioxide $\left(\mathrm{NO}_{2}\right)$, were observed in many places: China [4-10], Korea [11], Europe [12,13], the United States [14] and South America [15-17]. While such improvements in air quality were occasionally welcomed with positive and sometimes poetic phrases [7,18-20], the improvements are not evenly spread [21]. These are likely more nuanced than reported in the media [2,5], and not all cities experienced declines in air pollution [22,23]. Some authors have drawn attention to potential reductions in premature deaths as a result of improved air quality [24], though under lockdown it seems likely that the exposure would not be well-represented by outdoor measurements and there is a possibility of higher exposures indoors under lockdown [25-27].

Air pollution studies during the pandemic are not always easy to evaluate, as these have often reflected research at an early stage of an on-going crisis [28], with publications difficult to assess because of an absence of statistics or stringent control for emission or weather changes. While decreases in $\mathrm{NO}_{2}$ have been widely observed, these may not be paralleled for particulate material, which may be complicated by secondary aerosols [29] or sulphur dioxide, $\mathrm{SO}_{2}$ [30], while seasonal weather and changing chemistry can add confusion [31]. Peak air pollution concentrations might remain [32] and increased ozone levels that have accompanied the declines in nitrogen oxides (NOx) have been widely discussed [33-35]. Enhanced ozone has also offered the possibility that secondary aerosol concentrations would additionally increase, reminding us that emission and pollution is often linked by a complicated chemistry $[5,35]$. Some authors, additionally suggest that emissions might increase, as public transport is restricted [36].

Sydney, Australia represents an interesting case to study, as it had an increasingly stringent lockdown from mid-March, which was eased on 15 May. The restrictions followed a period of poor air quality because of bushfires late in 2019 [37,38]. Although media reports note Sydney's improved $\mathrm{NO}_{2}$ from satellite imagery, some suggest that pollution under lockdown in Melbourne and Perth might not have improved [39]. Most studies on the impact of COVID-19 on air quality have focused on cases where improvements have been dramatic, so here we address a case where change has been subtler. This paper examines $\mathrm{NO}_{2}, \mathrm{PM}_{2.5}, \mathrm{CO}, \mathrm{SO}_{2}$ and $\mathrm{O}_{3}$ (where $\mathrm{PM}_{2.5}$ refers to particles less than 2.5 microns across, $\mathrm{CO}$ refers to carbon monoxide and $\mathrm{O}_{3}$ refers to ozone), and considers what might have influenced the modest improvements seen in Sydney. We are additionally concerned with the relevance of social change and perceptions as portrayed on social media and within journalism and have become interested in the enthusiasm with which air quality improvements have been greeted, even where changes have probably been small.

\section{Materials and Methods}

This study focuses on Sydney, where there is a metropolitan population of more than five million in an urban area covering some $12,400 \mathrm{~km}^{2}$. The air pollution data come from official records from monitoring stations in and around the city. We used data from 2019 and 2020 through to the end of July; records are available at hourly intervals for six pollutants: $\mathrm{NO}_{2}, \mathrm{PM}_{2.5}, \mathrm{CO}, \mathrm{SO}_{2}$ and $\mathrm{O}_{3}$, along with nephelometric measurements of visibility. The more centrally located sites used here are: Randwick, Rozelle, Liverpool, Bringelly, Chullora, Earlwood, Richmond, Bargo, St Marys, Parramatta North, Oakdale, Prospect, Campbelltown West, Camden, Macquarie Park, Rouse Hill and Cook \& Phillip (Figure 1). Records are not always complete: data for Rouse Hill and Cook \& Phillip were not available for the early part of 2019. Carbon monoxide and sulphur dioxide had additional sites where data were not available. When comparing data sets, it became important to check that there were no large amounts of missing data, though we should note that five stations (Lindfield, Vineyard, MacArthur, Rouse Hill and Cook \& Phillip) often had to be omitted when comparing the two years because of gaps in the data. 


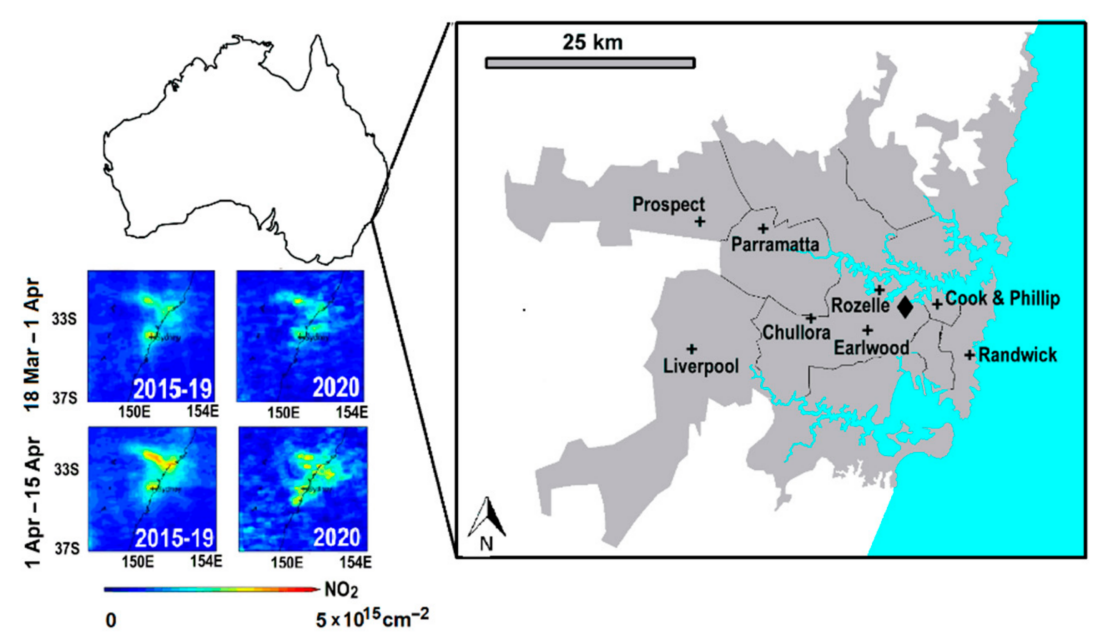

Figure 1. Map of the study area shows the sites in the inner parts of Sydney used in this study. The diamond marks the location traffic count data on the Western Distributor Road. The block of four images show the $\mathrm{NO}_{2}$ Aura/OMI column densities across the beginning of lockdown.

A range of online sources were used to access data in this project. This included air pollution measurements, satellite products and social and economic data available from the URLs below:

1. Concentration measurements are available from official air quality monitoring sites: https:/ / www.dpie.nsw.gov.au/air-quality / air-quality-data-services/data-downloadfacility

2. The satellite observations are available from the Copernicus Sentinel-5P Mapping Portal: https://maps.s5p-pal.com/ and also https://so2.gsfc.nasa.gov/no2/no2 _index.html

3. Counts to establish traffic flow are provided by Transport for NSW: https:/ / opendata. transport.nsw.gov.au/node/2171/exploreapi

4. Electricity generation data are available from the Australian Energy Market Operator: https:/ /www.aemo.com.au/energy-systems/electricity/national-electricitymarket-nem/data-nem/aggregated-data

5. The number of COVID-19 cases in Sydney extracted from statistics are available from the NSW Government: https:/ / data.nsw.gov.au/data/dataset/covid-19-cases-bylocation

6. Google Community Mobility Reports are available at: https://www.google.com/ covid19/mobility

7. Google trends was accessed using search terms at: https://trends.google.com/

Convenient images and data were not always available in periods that overlapped, so occasionally we have had to change time windows, as noted in the text. Data analysis used simple UNIX scripts and statistical calculations took advantage of the online calculators in Vassarstat (http:/ /vassarstats.net/) and WessaNet v.1.2.1 [40]. The $t$-test adopted was Welch's form as appropriate for unequal variance. Where the number of data elements were small or ordinal, non-parametric techniques were used, notably the Kendall rank correlation coefficient (statistic $\tau$ ) and the Wilcoxon signed-ranks test (statistic $W$ ). Pollution measurements from sites were often used as a daily average, but only retained when more than $20 \mathrm{~h}$ was available, except when relaxed for the non-parametric Wilcoxon signed rank test, where it was $15 \mathrm{~h}$.

The lockdown period started on 16 March 2020, followed by an increasingly stringent set of restrictions imposed under no less than seven NSW Public Health Orders; the final, and most restrictive, came into effect on 31 March. There was some easing on $15 \mathrm{May}$, and by 13 June, private homes could have as many as 20 visiting guests. From 1 July, there was 
further easing, although it became rather more restrictive again on 17 July [3], because of an increase in cases, which meant, for example, new rules for pubs being introduced.

\section{Results}

The results presented here consider concentration changes over from March 2019 to July 2020, a point at which the first wave of infections was largely over, and compare those under lockdown with column densities for $\mathrm{NO}_{2}$. These are then compared with perceptions and mobility changes over the lockdown period.

\subsection{Ground Level Pollutant Concentrations}

The average concentrations $\mathrm{NO}_{2}$ across Sydney are shown in Figure 2a, with the standard deviation bounded by a light grey line. The hourly values are smoothed as a 25-point running mean of hourly data to reflect roughly daily averages. It is always difficult to ascertain whether year-to-year differences arise from weather change or emissions [5], so caution is needed in subsequent interpretation. Nevertheless, the figure suggests that the period of lockdown in 2020 has concentrations that are a little lower. Air quality improvements under lockdown have often compared values with those of earlier years, frequently presented as satellite images [6], which give a strong visual confirmation of change (block-of-four satellite images in Figure 1). Even with $\mathrm{NO}_{2}$, the most sensitive marker of change, the declines seen in ground level measurements under lockdown may be subtle $[2,13,21,41,42]$. Welch's $t$-test suggests that Sydney's daily averages for April in 2019 and the same month of 2020 are not significantly different ( $\left.p_{1} \sim 0.15\right)$, although the mean concentrations $8.52 \pm 1.92$ and $7.85 \pm 2.92 \mathrm{ppb}$ would suggest a modest improvement, during this period of stringent lockdown. Comparisons between the two years may be unreliable because some $20 \%$ of the data are missing. However, we were reassured that an additional station-by-station analysis (individual details see Table A1) examining only those days where $>15 \mathrm{~h}$ of data are available, showed that the median daily values were lower in 2020, for only 9 of the 15 sites.

A similar situation over lockdown pertains to daily average $\mathrm{PM}_{2.5}$ concentrations as illustrated in Figure 2b, with the April differences between 2019 and 2020, $8.91 \pm 4.94$ and $7.95 \pm 2.64 \mu \mathrm{g} \mathrm{m}^{-3}$, but again, these are not significantly different $\left(p_{1} \sim 0.18\right)$. The bushfires from November 2019 had a detrimental effect on air quality [43], with a set of increasingly higher and more frequent peaks in $\mathrm{PM}_{2.5}$ over Sydney through November, becoming almost continuous in December. Figure 2c suggests a small respite towards the end of December, but further increases over the last few days of the year, which are also seen in the record from TropOMI described by Khaykin et al. [38]. They observed a

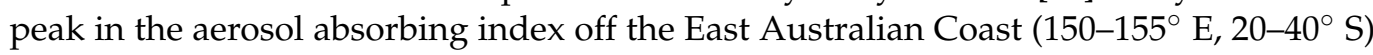
on 22 December with a gap and then a further peak on 31 December, declining through the first week of January. The ground level measurements of Ulpiani et al. [43] detail the changes in Sydney across the period of 20 December 2019 until 13 January 2020, and show slight decreases in $\mathrm{PM}_{10}$ over the Christmas period, but higher concentrations into the New Year. While the spatial extent and averaging times between the ground level and satellite measurements are different, they show a satisfying agreement.

We can also see the effect of bushfires on the CO concentrations, as shown Figure 2c. The CO data assembled from the 11 monitoring sites are rather patchy, but CO is of ten fairly evenly spread across cities, so the picture is probably a coherent one, despite the missing data. The differences in CO in April for 2019 and 2020 are $0.227 \pm 0.049$ and $0.201 \pm 0.040 \mathrm{ppm}$, respectively, with Welch's $t$-test suggesting a significant decrease $\left(p_{1}=0.013\right)$. This is a clear change over a year, but hardly convincing, as such short periods could readily differ from one year to the next. Although a comparison with the previous year has been a popular tool to show the effect of emission reductions under lockdown, it fails to account for weather differences between years. It can be argued that daily and weekly cycles may be less sensitive to this [42]. There are hints of shifts in the diurnal cycle, although these are slight in most cases for the Sydney data. However, in 
the case of a few individual sites, there appears to be a loss of the broad peak across the morning, which might suggest changes that resulted from the lockdown, but by-and-large, these remained unconvincing. There is a slight decrease in $\mathrm{SO}_{2}$ between 2019 and 2020 (Figure 2d): $0.60 \pm 0.41$ and $0.48 \pm 0.38 \mathrm{ppb}$, respectively, but the $t$-test suggests this is not significant $\left(p_{1} \sim 0.13\right)$. Ozone shows a slight, though barely significant $\left(p_{1} \sim 0.09\right)$ increase from $14.2 \pm 3.3$ to $15.4 \pm 3.5 \mathrm{ppb}$ (Figure 2e), as often observed because of decreasing NOx emissions under lockdown.
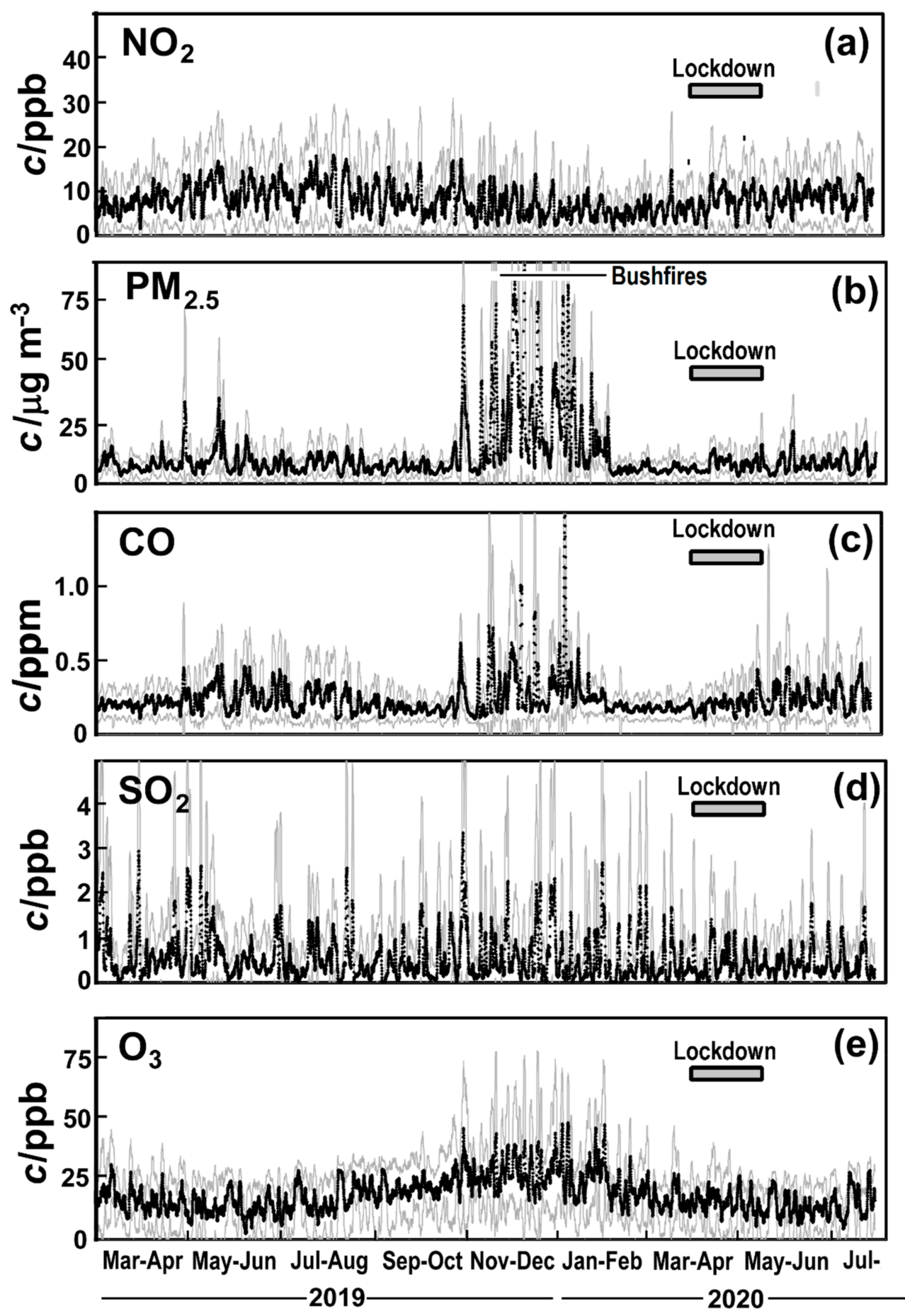

Figure 2. The $25 \mathrm{~h}$ running mean of (a) $\mathrm{NO}_{2}$, (b) $\mathrm{PM}_{2.5}$, (c) $\mathrm{CO}$, (d) $\mathrm{SO}_{2}$ and (e) $\mathrm{O}_{3}$ concentrations across Sydney from March 2019 to July 2020. The grey lines mark the standard deviation (negative values not plotted). Note: lockdown period marked as grey bar and the period of bushfires by the horizontal line in (b), see [38] for details. 


\subsection{Column Density from Satellite Observations}

Early observations of the impact of lockdown on air pollution often came from column density as measured by satellite $[6,9,44]$. These frequently relied on the TropOMI instrument on the sun-synchronous Sentinel-5 Precursor satellite, which has an overpass time of 13:30. TropOMI uses a range of wavelengths to provide measurements for a range of pollutants such as: $\mathrm{O}_{3}, \mathrm{NO}_{2}, \mathrm{SO}_{2}, \mathrm{CO}$ and aerosols with daily coverage at a maximum $3.5 \mathrm{~km} \times 5.5 \mathrm{~km}$ resolution. The measurements are usefully averaged over longer times (i.e., two weeks and part of the satellite product) and for $\mathrm{NO}_{2}$, which has generally been studied because the changes are clearest [6]. The 15-day averaged images over the lockdown period are plotted in Figure 3a-e. There appears to be a dramatic visual decline in Sydney from late March (15-30) into early April, although column densities returned to higher values later in the month. These were well-reported in the media, e.g., The Conversation [39]. However, these changes were not universal, and by contrast, The Conversation noted that $\mathrm{NO}_{2}$ increased by $20 \%$ for Newcastle, with the country's largest concentration of coal-burning heavy industry, increasing by $40 \%$ for Melbourne, a sprawling city strongly dependent on cars, whereas Perth showed no real change.
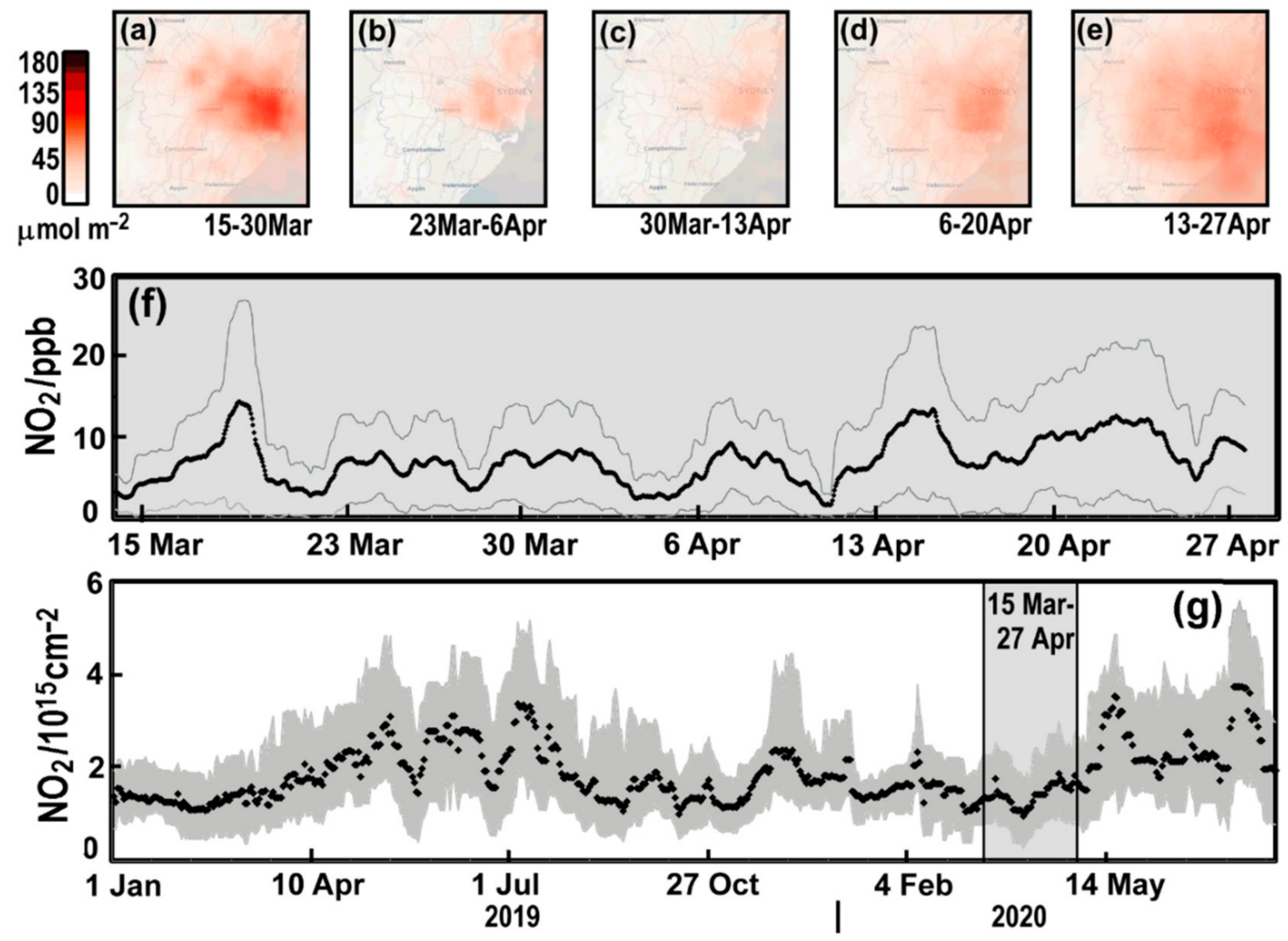

Figure 3. Satellite imagery of the $\mathrm{NO}_{2}$ column density over the Sydney area from the Sentinel 5P TropOMI instrument for the dates (a) 15-30 March, (b) 23 March-6 April, (c) 30 March-13 April, (d) 6-20 April and (e) 13-27 April; (f) the 25-h running mean of surface $\mathrm{NO}_{2}$ concentrations across the Sydney sites and (g) measurements of column density of $\mathrm{NO}_{2}$ from across the period January 2019 to July 2020 from the Aura OMI system.

Satellite products are atmospheric column measurements that have a different spatiotemporal resolution compared with ground level measurements. Thus, they may not capture just how variable ground level concentrations may be (Figure 3f). As noted in the previous section, the lockdown period is not especially distinctive in terms of ground level concentrations, although ground level $\mathrm{NO}_{2}$ was low in early April and the 10-13th of April, which corresponds with the Easter holidays. There are some gaps in the instrumental record in the first days of April, though it is likely that the concentrations of $\mathrm{NO}_{2}$ were nevertheless rather low, as illustrated in Figure 3f. The general impression given by the 
satellite maps agrees with the measured ground level trend, i.e., low concentrations in early April, rising later that month. The column density of $\mathrm{NO}_{2}$ over longer periods is given in Figure $3 g$, which reminds us that these vary and show a distinct seasonality (i.e., higher in winter than summer). This might explain the rise in concentrations throughout April. The inset to Figure $3 \mathrm{~g}$ for the 46-day period covering the five TropOMI maps shows that ground level daily average $\mathrm{NO}_{2}$ concentrations for Sydney are well-correlated (Kendall $\tau=0.38, p<0.00025$ ), with median daily column densities from the Aura OMI system [45].

Satellite imagery can be very dramatic, with vivid colours contributing to an impression of a "vastly lower concentration of air pollution" under lockdown [39], even though the changes might in reality be quite modest. This may have arisen from the saturated colours associated with published images, and perhaps also because of the smooth integration of $\mathrm{NO}_{2}$ across time and space. These might enhance an impression of change.

\subsection{Emissions, Human Mobility and Electricity Production}

A key reason to expect air quality to improve under lockdown is the reduction in emissions from industry and transport, although many accounts do not present detailed values for these reductions. The tabulation found in Kumar et al. [46] suggests that papers discussing emission reduction may take measurements of concentration or column density reduction as the indicator, rather than determine emissions independently. Many perhaps seeing reductions under lockdown as inevitable. However, Li et al. [47] estimated emission reductions across the Yangtze River Delta during restrictions where vehicle emission reduced by three quarters, while stationary sources were down only a third. Human mobility is a key element to changes under lockdown, though understandably, some sources, such as domestic cooking emissions, are likely to increase. Emissions from Sydney are available in detail for 2013 [48], but as the reports take many years to generate, it represents the most recent set of consolidated results for natural and human-made emissions. We can see from Table 1 that traffic emissions represent almost half of the source for $\mathrm{CO}$ and $\mathrm{NOx}$, but represents only $\sim 10 \%$ of the particulate emissions. Some 5000 tonne $\mathrm{PM}_{2.5}$ comes each year from domestic solid fuel combustion and represents just over half the total emissions in Sydney.

Table 1. Total estimated emissions (units: $\mathrm{Mg} \mathrm{a}^{-1}$ i.e., tonne per annum) and percentage of total in parentheses from in Sydney for 2013 extracted from Air Emissions Inventory for the Greater Metropolitan Region in New South Wales, NSW Environment Protection Authority, Sydney. EPA 2019P1917.

\begin{tabular}{ccccccc}
\hline & Commercial & $\begin{array}{c}\text { Domestic } \\
\text { Commercial }\end{array}$ & Industrial & Off-Road & On-Road & Total \\
\hline $\mathrm{CO}$ & $320(<1)$ & $90,299(43)$ & $5968(3)$ & $22,465(11)$ & $91,239(43)$ & 210,291 \\
$\mathrm{NOx}$ & $359(1)$ & $2701(5)$ & $7387(13)$ & $15,734(27)$ & $32,496(55)$ & 58,676 \\
$\mathrm{PM}_{10}$ & $682(4)$ & $5744(37)$ & $6040(39)$ & $1111(7)$ & $1838(12)$ & 15,415 \\
$\mathrm{PM}_{2.5}$ & $291(3)$ & $5517(55)$ & $1824(18)$ & $1034(10)$ & $1279(13)$ & 9945 \\
$\mathrm{SO}_{2}$ & $79(1)$ & $124(1)$ & $3057(30)$ & $6790(67)$ & $98(1)$ & 10,148 \\
\hline
\end{tabular}

Even under the limited January lockdown in Guangdong Province, far from the COVID-19 epicentre in Wuhan, residents still cancelled unnecessary trips [49], so changes in human mobility are readily affected by social pressures. Traffic restrictions were widespread [36] and in Beijing, where limited areas of the city were closed after a COVID-19 outbreak at Xinfadi Market in April, mobile phone data suggest wider reductions in activity across the city; at shopping malls and amusement parks [50]. The changing location of Sydney residents (Figure 4a) can be explored using Google's Community Mobility Reports, which aggregate anonymised sets of hourly data from users with Location History set on. The normalised output shown has been smoothed with a 7-day running mean to remove the weekly cycle. Time spent at home rose in the first weeks of March, the very beginning of the lockdown, even though it was not initially very stringent. Through the second half of March, there was a transition to tougher restrictions. Australians spent $25 \%$ of their time 
working and commuting, $\sim 10 \%$ on recreational activities, $15 \%$ at home (social media, TV etc.) and 30\% sleeping, with domestic duties and recreation taking 20\% [51]. This means that two-thirds of their time was already spent at home, so a $30 \%$ change is substantial, and indicates that Sydney residents were most likely at home. This makes the concerns of Ezani et. al. [25] over the exposure to air pollutants in the domestic environment seem quite reasonable. The proportion of time spent at home grew gradually as Public Health Orders became stricter; by the 4th Order of 23 March, social life in the city was virtually suspended. Time-at-home reached a plateau at the beginning of April after a final Order was put in place on 31 March. However, there are hints that people were already aware of the significance of changes underway. The use of the transit system and parks declined just prior to mid-March and time in the workplace soon after. Shopping for grocery and pharmaceutical items showed a positive peak centred around the weekend of 14-15 March, only to decline a little later, lagging by a week or more compared with other reductions. Overall, the picture is one that suggests a large degree of compliance.
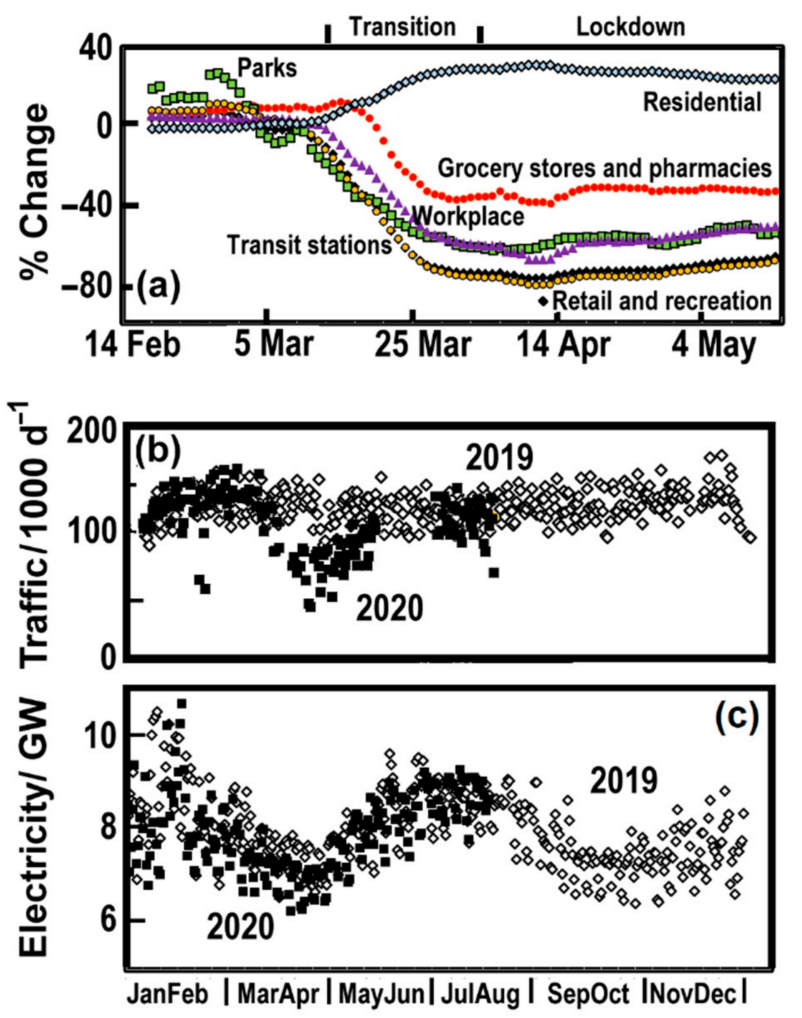

Figure 4. (a) Changing location of residents of Sydney using Google's Community Mobility Reports, showing percentage change at various sites. (b) The daily traffic flow in both directions along Sydney's Western Distributor in 2019 and the first part of 2020. (c) Average daily power output for New South Wales for both 2019 and 2020. Note: in (b,c), 2019 is represented with open white diamonds and 2020 with filled squares.

The changed mobility was also reflected in decreased traffic flow from a vehicle census on the Western Distributor (marked as a diamond in Figure 1), as shown in for 2019 (Figure 4b) and 2020 (Figure 4c), suggesting a 50\% decrease as restrictions were implemented. Even by the end of June, traffic flow had not fully recovered; this slow recovery has been observed elsewhere [50]. There is also a general perception that industrial emissions would drop, though clearly electricity supply is still needed at perhaps only a slightly reduced amount even under lockdown. In Sydney the five coal generating plants, though 90-240 km distant, were often seen as a contributor to the city's air pollution. However, two of the four units at Liddell (170 km distant) were out of action and one at the nearby Bayswater power station ( $240 \mathrm{~km}$ distant). Over four hours of Easter Saturday 
(11 April), renewable energy provided more than half of the power for the electricity market. The demand for the State of New South Wales was low, under the restriction in early April, as seen in Figure 4c although recovery was rapid. Overall, the traffic patterns and their emissions changed in Sydney during lockdown, but energy generation shows lower emissions. As a public heath response, lockdown achieved some success, with the number of new COVID-19 cases falling dramatically by April 14, although Australia and New Zealand continued to impose tight restrictions on travel and public gatherings.

\subsection{Icons and Media Visions}

The notion that air pollution was reduced by the COVID-19 pandemic [6] is widely spread within the popular media. It seemed likely that the public viewpoint was shaped by journalism, although Sekar et al. [52] claimed otherwise for the Indian population in their paper on public perception of air quality during COVID-19: "It is evident that the respondents perceived improvement in air quality without the influence of media". The argument about an improved environment has been extended with the view that many lives were saved through improved air quality $[24,53]$. This has gained support from academic articles, so it is seen to represent a silver lining to clouds of COVID despair [7,18-20]. Nevertheless, a number of papers have questioned the universality of such visions and regard improvements in air pollution as more nuanced than portrayed by the media (e.g., [7]), with health benefits overstated or in need of more rigorous analysis and clear caveats $[28,54-56]$.

The acceptance of greatly improved air quality was potentially aided by some iconic satellite imagery that matches the eye-catching colours of the ozone hole; a seemingly indelible and well-accepted icon [57]. Such imagery has been frequently used in media representations as a graphic illustration of change, with false-colour representations surprisingly readable [58]. However, satellite images represent column densities, and in the case of media presentations during COVID-19, they were smoothed over large areas across many days (e.g., [39]). This means that although these gave a good sense of longer-term change in emissions, the published satellite imagery might not represent day-to-day changes in perceived visibility, or even less, the hour-long ground level exposure to $\mathrm{NO}_{2}$ relevant to health concerns. Nevertheless, the vivid nature of the imagery often looks so convincing that it may inhibit extended reflection on the subtly of the changes and the high degree of variation.

The impression of change to air quality in Sydney may have been enhanced by contrast with that experienced during the extensive bushfires of late 2019. Pictures of Sydney obscured by smoke were widely shared by the global media. There were nearapocalyptic images of Sydney's famous Harbour Bridge and Opera House under orange skies, along with pictures of rescued koalas that have become indelibly linked to the period. Visibility can be a key perception for the public in defining air pollution [59]. During the lockdown in April, media comments drew attention to Sydney's air, which had recovered from the smoke of previous months. Journalist Peter Hannam [37], wrote that the "virus and favourable weather delivers clear skies over Sydney", while acknowledging bushfires had been important in generating high $\mathrm{PM}_{2.5}$ concentrations. The dramatic changes must have made it easy to see lockdown as a time of cleaner air, a case well-supported by satellite imagery and Figure 2b, where we can see rapid changes between bad days and days that were less affected.

The media also reflected on the lockdown period as a catalyst for wider environmental and social change once the pandemic ends [60]. People potentially have more time for reflection on environmental issues under lockdown, when they are distanced from the hustle-and-bustle of daily life. In addition, as often reported in the media, lockdown has led to some improvements in the natural world, with more wild-flowers and animals [61]. Equally, any recovery may bring with it increased pressure on the environment; there is, rightly, public cynicism about short-term responses to improving environmental quality [59]. 


\subsection{Popular Opinion}

The lockdown period may have been one where the balance of perceptions of air pollution was different. This was explored using Google Trends, which determines the frequency of search queries on Google. Some of these search terms are compared with the daily number of cases in Sydney in Figure 5.

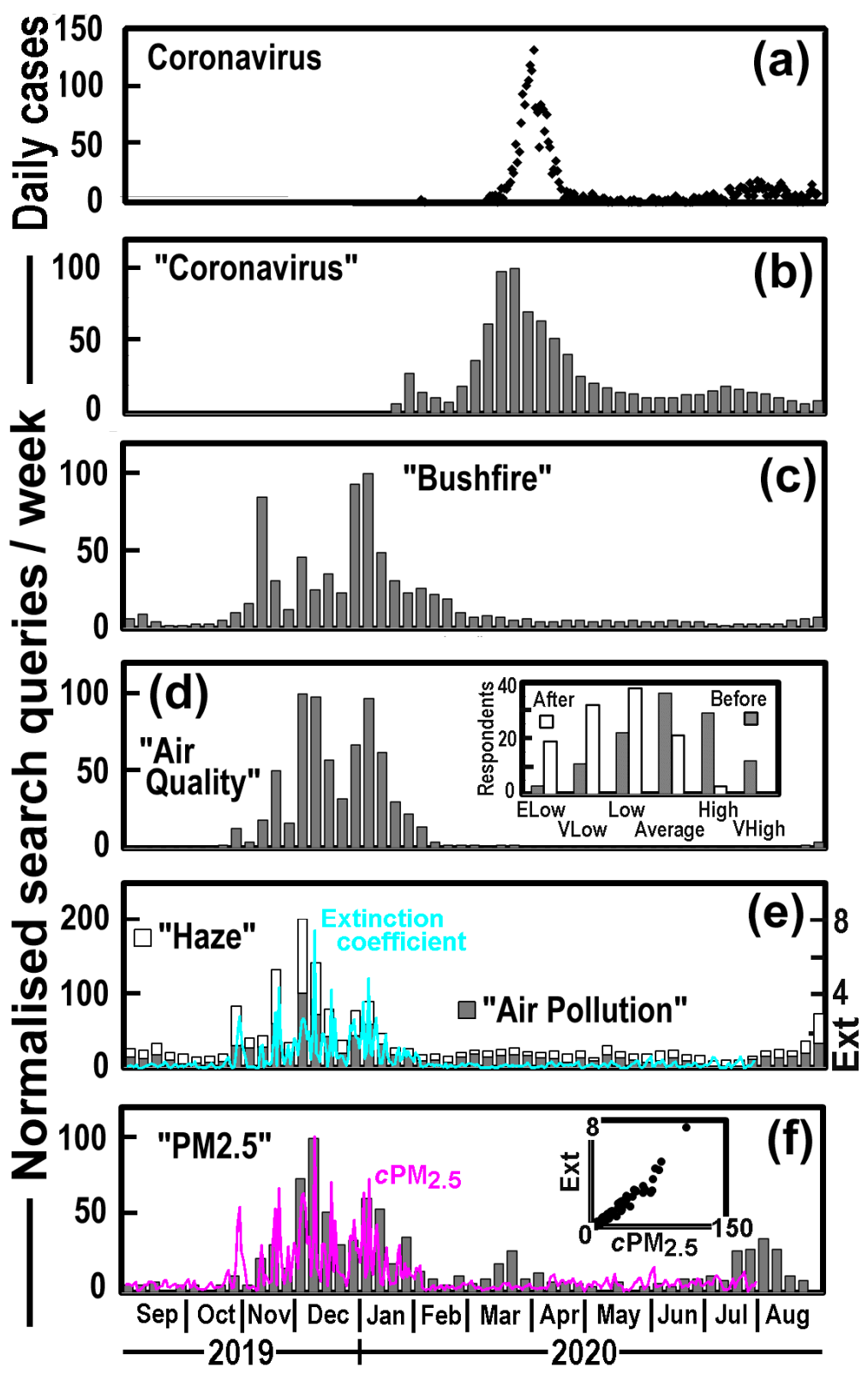

Figure 5. (a) The daily number of COVID-19 cases in Sydney. Normalised weekly search terms from Google Trends for New South Wales for (b) "Coronavirus" (c) "bushfire" (d) "air quality" with an inset histogram of assessment of air pollution before (grey) and after (white) lockdown; (e) search terms "haze" and "air pollution" and a light-coloured line denoting extinction coefficient (units: $\mathrm{Mm}^{-1}$ ) estimated from a visual range; (f) search term " $\mathrm{PM}_{2.5}$ " and a light-coloured line denoting the average daily $\mathrm{PM}_{2.5}$ concentration (units: $\mu \mathrm{g} \mathrm{m}^{-3}$ ). The inset to (f) shows the extinction coefficient (y-axis: $\left.0-8 \mathrm{Mm}^{-1}\right)$ as a function of the daily mean $\mathrm{PM}_{2.5}$ for Sydney $\left(x\right.$-axis: $\left.0-150 \mu \mathrm{g} \mathrm{m}^{-3}\right)$.

Although the search terms usage comes from NSW, the data are useful here, as a large proportion are from Sydney and nearby Wollongong. Not surprisingly, the search term "coronavirus", matches, and perhaps even slightly precedes, the rising number of 
cases in Sydney. Google Trends suggests that while searches rose very steeply during lockdown (Figure $5 b$ ), they fell during lockdown, only to rise again from late June, showing that interest persisted, as the crisis was global and concern grew about a second wave. Australia has had a second wave, but this was seen mostly in Melbourne [62]. While Sydney experienced only modest changes, it was anxious to avoid the second wave found in Melbourne. A small number of cases derived from Victoria were found in Sydney by July.

"Bushfires" as a search term (Figure 5c) proves contemporaneous with the term "air quality" (Figure 5d) and are associated with the fires late in 2019. Barbieri et al. [63] surveyed pre- and post-lockdown perceptions of air quality in: Australia, Brazil, China, Ghana, India, Iran, Italy, Norway, South Africa and the United States using an online questionnaire hosted on two platforms: Google Forms and Wen Juan Xing. Globally citizens did not regard the amount of air pollution as high during the COVID-19 restrictions. This was also clear in NSW (inset to Figure 5d), where on the Likert scale used in the survey, there is a decline in the number of respondents reporting high or average air quality after the lockdown was in place. A pairwise comparison was significant $n=113$; $W=3637 ; p_{1}<0.0001$ ). A single respondent thought air pollution had become worse, though 27 thought there was no difference. Elsewhere in Australia, people generally believed air pollution had improved $\left(n=274 ; W=13372 ; p_{1}<0.0001\right)$, though a larger proportion (40\%) than in Sydney thought it unchanged.

The terms "haze" and "air pollution" (Figure 5e), though spread more widely over time, were frequent over the period of intense fires. There is a satisfying relationship between these terms and the extinction coefficient (inverse of visibility) measured by nephelometry at the air pollution monitoring sites (shown as a light-coloured line). The more specific term " $\mathrm{PM}_{2.5}$ " (Figure 5f) is associated with the bush fires, but it shows up in a number of other periods where the search term was used at higher frequency; thus, there may be some association with the lockdown. The daily $\mathrm{PM}_{2.5}$ concentrations (light-coloured line) and the inset shows an excellent agreement between particulate concentrations and the extinction coefficient, as has often been observed [64]. The strong links between the terms bushfire smoke, visibility, $\mathrm{PM}_{2.5}$ and air quality at the end of 2019 may well have added to an impression of improved air quality during lockdown. However, there appeared by comparison only a weak association with air pollution searches using the terms "air quality", "haze" and "air pollution" during lockdown. Neither the search terms " $\mathrm{NO}_{2}$ " or "nitrogen dioxide" showed any trends or peaks in NSW across the period and few searches relate to "Tropomi", "Copernicus" or "Sentinel" in Australia.

\section{Conclusions}

Emission reductions under lockdown and other restrictions has generally led to decreases in primary air pollutants, most evident in $\mathrm{NO}_{2}$. The changes in other pollutants such as $\mathrm{PM}_{2.5}, \mathrm{CO}$ and $\mathrm{SO}_{2}$ may have been more variable, and regionally, $\mathrm{O}_{3}$ was typically observed to increase. Given the relatively low level of pollutants in Australia, it is not surprising that improvements were modest under lockdown, even though the population was largely compliant in terms of reduced mobility. It may be argued that the magnitude of emission driven-changes might be obscured by seasonal or year-to-year variations in weather. However, the perceptions of air quality at interest here relate to the concentrations experienced (as in Figure 2) and naturally make no allowance for weather change. A significant fraction of the Australians surveyed thought air pollution had improved during lockdown.

The extent of perceived improvement in air quality may have been emphasised by the widely distributed satellite imagery from around the globe. False-colours may have added drama to the change, especially given that satellite column densities have a spatio-temporal resolution that differs from ground level. Residents of Sydney might have, very reasonably, made a comparison between the sparkling air during lockdown and the bushfire haze just a few months earlier. This link emerges in the analysis of search terms from Google Trends. 
There may also have been a natural desire to accept stories of an improved environment at a time of crisis. The work presented here should remind us that air pollution is as much an event of society, as it is one of emissions and meteorology. Successful regulation of air quality likely requires maintaining a delicate balance between our social perceptions and physical reality.

Author Contributions: Conceptualisation, methodology and review and editing, P.B. and Y.L.; formal analysis, P.B.; data curation, Y.L. All authors have read and agreed to the published version of the manuscript.

Funding: This research received no external funding.

Institutional Review Board Statement: Not applicable.

Informed Consent Statement: Not applicable.

Data Availability Statement: Not applicable.

Conflicts of Interest: The authors declare no conflict of interest.

\section{Appendix A}

Table A1. (ppm) and $\mathrm{PM}_{2.5}\left(\mu \mathrm{g} \mathrm{m}{ }^{-3}\right)$, with more than $15 \mathrm{~h}$ of data, from the site for the month of April in 2019 and 2020 along with the $p$ values associated with the difference between the means determined from Welch's $t$-test.

\begin{tabular}{ccccccccccc}
\hline Site & \multicolumn{2}{c}{$\mathbf{2 0 1 9}$} & \multicolumn{2}{c}{$\mathbf{2 0 2 0}$} & \multicolumn{1}{c}{$\boldsymbol{t}$-Test } & \multicolumn{2}{c}{$\mathbf{2 0 1 9}$} & \multicolumn{2}{c}{$\mathbf{2 0 2 0}$} & $\boldsymbol{t}$-Test \\
\hline & $\boldsymbol{c}_{\text {NO2 }}$ & $\boldsymbol{\sigma}_{\text {NO2 }}$ & $\boldsymbol{c}_{\text {NO2 }}$ & $\boldsymbol{\sigma}_{\text {NO2 }}$ & $\boldsymbol{p}_{\text {NO2 }}$ & $\boldsymbol{c}_{\text {PM2.5 }}$ & $\boldsymbol{\sigma}_{\text {PM2.5 }}$ & $\boldsymbol{c}_{\text {PM2.5 }}$ & $\boldsymbol{\sigma}_{\text {PM2.5 }}$ & $p_{\text {PM2.5 }}$ \\
\hline Randwick & 9.83 & 3.96 & 8.37 & 4.19 & 0.1371 & 9.58 & 5.29 & 8.22 & 3.21 \\
Rozelle & 10.69 & 3.13 & 10.34 & 4.75 & 0.3740 & 8.80 & 4.82 & 7.11 & 3.20 & 0.120 \\
Liverpool & 13.02 & 2.45 & 12.90 & 5.10 & 0.4545 & 10.66 & 6.94 & 9.22 & 3.94 & 0.163 \\
Bringelly & 5.29 & 1.60 & 5.21 & 1.32 & 0.4307 & 7.93 & 4.00 & 8.48 & 3.34 & 0.285 \\
Chullora & 11.99 & 2.62 & 12.73 & 4.17 & 0.2313 & 10.19 & 7.60 & 7.95 & 3.13 & 0.082 \\
Earlwood & 10.86 & 2.44 & 10.24 & 4.71 & 0.2729 & 9.21 & 6.31 & 7.39 & 3.56 & 0.089 \\
Richmond & 4.79 & 1.10 & 3.58 & 1.15 & 0.0004 & 8.12 & 3.46 & 8.90 & 3.39 & 0.197 \\
Bargo & 7.93 & 2.35 & 8.60 & 3.99 & 0.2560 & 9.50 & 6.87 & 7.16 & 2.76 & 0.050 \\
St Marys & 4.68 & 1.77 & 5.58 & 1.68 & 0.0398 & 7.35 & 2.90 & 8.22 & 2.72 & 0.129 \\
Parramatta & 10.88 & 2.68 & 9.42 & 2.84 & 0.0294 & 7.56 & 3.77 & 7.36 & 2.97 & 0.413 \\
Oakdale & 2.29 & 0.92 & 2.33 & 1.10 & 0.4507 & 8.31 & 3.94 & 9.52 & 1.87 & 0.079 \\
Prospect & 10.16 & 2.64 & 9.97 & 3.02 & 0.4071 & 9.34 & 4.22 & 8.57 & 3.98 & 0.237 \\
Campbelltown & 11.15 & 2.22 & 12.53 & 4.54 & 0.0799 & 12.99 & 12.17 & 7.75 & 2.96 & 0.021 \\
Camden & 5.53 & 1.78 & 4.60 & 2.08 & 0.0430 & 9.53 & 10.08 & 8.12 & 2.81 & 0.238 \\
Macquarie & 5.70 & 2.21 & 4.92 & 1.81 & 0.0780 & 6.82 & 3.24 & 6.22 & 2.62 & 0.216 \\
\hline
\end{tabular}

\section{References}

1. Leung, K.; Wu, J.T.; Liu, D.; Leung, G.M. First-wave COVID-19 transmissibility and severity in China outside Hubei after control measures, and second-wave scenario planning: A modelling impact assessment. Lancet 2020, 395, 1382-1393. [CrossRef]

2. Brimblecombe, P.; Lai, Y. Effect of fireworks, Chinese New Year and the COVID-19 lockdown on air pollution and public attitudes. Aerosol Air Qual. Res. 2020, 20, 2318-2331. [CrossRef]

3. Mills Oakley, Melbourne. Available online: https://www.millsoakley.com.au/thinking/nsw-under-official-lockdown-fulldetails-of-new-government-directions-now-published/ (accessed on 1 January 2021).

4. Bao, R.; Zhang, A. Does lockdown reduce air pollution? Evidence from 44 cities in northern China. Sci. Total Environ. 2020, 731, 139052. [CrossRef] [PubMed]

5. Fan, C.; Li, Z.; Li, Y.; Dong, J.; van der A, R.; de Leeuw, G. Does reduction of emissions imply improved air quality? Atmos. Chem. Phys. Discuss. 2020. [CrossRef]

6. Dutheil, F.; Baker, J.S.; Navel, V. COVID-19 as a factor influencing air pollution? Environ. Pollut. 2020, 263, 114466. [CrossRef]

7. Muhammad, S.; Long, X.; Salman, M. COVID-19 pandemic and environmental pollution: A blessing in disguise? Sci. Total Environ. 2020, 728, 138820. [CrossRef]

8. Pei, Z.; Han, G.; Ma, X.; Su, H.; Gong, W. Response of major air pollutants to COVID-19 lockdowns in China. Sci. Total Environ. 2020, 743, 140879. [CrossRef] 
9. Wang, Q.; Su, M. A preliminary assessment of the impact of COVID-19 on environment-A case study of China. Sci. Total Environ. 2020, 728, 138915. [CrossRef]

10. Yue, X.; Lei, Y.; Zhou, H.; Liu, Z.; Letu, H.; Cai, Z.; Lin, J.; Jiang, Z.; Liao, H. Changes of anthropogenic carbon emissions and air pollutants during the COVID-19 epidemic in China. Trans. Atmos. Sci. 2020, 43, 265-274.

11. Seo, J.H.; Jeon, H.W.; Sung, U.J.; Sohn, J.R. Impact of the COVID-19 Outbreak on Air Quality in Korea. Atmosphere 2020, $11,1137$. [CrossRef]

12. Menut, L.; Bessagnet, B.; Siour, G.; Mailler, S.; Pennel, R.; Cholakian, A. Impact of lockdown measures to combat Covid-19 on air quality over western Europe. Sci. Total Environ. 2020, 741, 140426. [CrossRef]

13. Tobías, A.; Carnerero, C.; Reche, C.; Massagué, J.; Via, M.; Minguillón, M.C.; Alastuey, A.; Querol, X. Changes in air quality during the lockdown in Barcelona (Spain) one month into the SARS-CoV-2 epidemic. Sci. Total Environ. 2020, 726, 138540. [CrossRef]

14. Berman, J.D.; Ebisu, K. Changes in US air pollution during the COVID-19 pandemic. Sci. Total Environ. 2020, $739,139864$. [CrossRef] [PubMed]

15. Dantas, G.; Siciliano, B.; França, B.B.; da Silva, C.M.; Arbilla, G. The impact of COVID-19 partial lockdown on the air quality of the city of Rio de Janeiro, Brazil. Sci. Total Environ. 2020, 729, 139085. [CrossRef] [PubMed]

16. Nakada, L.Y.K.; Urban, R.C. COVID-19 pandemic: Impacts on the air quality during the partial lockdown in São Paulo state, Brazil. Sci. Total Environ. 2020, 730, 139087. [CrossRef] [PubMed]

17. Pacheco, H.; Díaz-López, S.; Jarre, E.; Pacheco, H.; Méndez, W.; Zamora-Ledezma, E. NO2 levels after the COVID-19 lockdown in Ecuador: A trade-off between environment and human health. Urban Clim. 2020, 34, 100674. [CrossRef] [PubMed]

18. Huang, L.; Liu, Z.; Li, H.; Wang, Y.; Li, Y.; Zhu, Y.; Ooi, M.C.G.; An, J.; Shang, Y.; Zhang, D.; et al. The silver lining of COVID-19: Estimation of short-term health impacts due to lockdown in the Yangtze River Delta region, China. GeoHealth 2020, 4, e2020GH000272. [CrossRef]

19. Lal, P.; Kumar, A.; Kumar, S.; Kumari, S.; Saikia, P.; Dayanandan, A.; Adhikari, D.; Khan, M.L. The dark cloud with a silver lining: Assessing the impact of the SARS COVID-19 pandemic on the global environment. Sci. Total Environ. 2020, $732,139297$. [CrossRef]

20. Ramasamy, D.; Jayakumar, S.; Somasundaram, M. Enchanted Improvements in Air Quality across India-A Study from COVID-19 Lockdown Perspective. Adalya 2020, 9. [CrossRef]

21. Schiermeier, Q. Why pollution is plummeting in some cities-but not others? Nature 2020, 580, 313. [CrossRef]

22. Rodríguez-Urrego, D.; Rodríguez-Urrego, L. Air quality during the COVID-19: PM2. 5 analysis in the 50 most polluted capital cities in the world. Environ. Pollut. 2020, 266, 115042. [CrossRef] [PubMed]

23. Shrestha, A.M.; Shrestha, U.B.; Sharma, R.; Bhattarai, S.; Tran, H.N.T.; Rupakheti, M. Lockdown caused by COVID-19 pandemic reduces air pollution in cities worldwide. Eartharxi 2020. [CrossRef]

24. Karuppasamy, M.B.; Seshachalam, S.; Natesan, U.; Ayyamperumal, R.; Karuppannan, S.; Gopalakrishnan, G.; Nazir, N. Air pollution improvement and mortality rate during COVID-19 pandemic in India: Global intersectional study. Air. Qual. Atmos. Health 2020, 13, 1-10. [CrossRef]

25. Ezani, E.; Brimblecombe, P.; Asha'ari, Z.H.; Fazil, A.A.; Ismail, S.N.S.; Ramly, Z.T.A.; Khan, M.F. Indoor exposure to PM2.5 during COVID-19 lockdown in suburban Malaysia. Aerosol Air Qual. Res. 2020, 20. [CrossRef]

26. Nwanaji-Enwerem, J.C.; Allen, J.G.; Beamer, P.I. Another invisible enemy indoors: COVID-19, human health, the home, and United States indoor air policy. J. Expo. Sci. Environ. Epidemiol. 2020, 30, 773-775. [CrossRef]

27. Saha, J.; Chouhan, P. Indoor air pollution (IAP) and pre-existing morbidities among under-5 children in India: Are risk factors of coronavirus disease (COVID-19)? Environ. Pollut. 2020, 266, 115250. [CrossRef]

28. Heederik, D.J.; Smit, L.A.; Vermeulen, R.C. Go slow to go fast: A plea for sustained scientific rigour in air pollution research during the COVID-19 pandemic. Eur. Respir. J. 2020, 56, 2001361. [CrossRef]

29. Zhu, S.; Wang, Q.; Qiao, L.; Zhou, M.; Wang, S.; Lou, S.; Huang, D.; Wang, Q.; Jing, S.; Wang, H.; et al. Tracer-based characterization of source variations of PM2. 5 and organic carbon in Shanghai influenced by the COVID-19 Lockdown. Faraday Discuss. 2020. [CrossRef]

30. Higham, J.E.; Ramírez, C.A.; Green, M.A.; Morse, A.P. UK COVID-19 lockdown: 100 days of air pollution reduction? Air Qual. Atmos. Health 2020, 1-8. [CrossRef]

31. Huang, Y.; Zhou, J.L.; Yu, Y.; Mok, W.C.; Lee, C.F.; Yam, Y.S. Uncertainty in the impact of the COVID-19 pandemic on air quality in Hong Kong, China. Atmosphere 2020, 11, 914. [CrossRef]

32. Wang, P.; Chen, K.; Zhu, S.; Wang, P.; Zhang, H. Severe air pollution events not avoided by reduced anthropogenic activities during COVID-19 outbreak. Resour. Conserv. Recycl. 2020, 158, 104814. [CrossRef] [PubMed]

33. Huang, X.; Ding, A.; Gao, J.; Zheng, B.; Zhou, D.; Qi, X.; Tang, R.; Wang, J.; Ren, C.; Nie, W.; et al. Enhanced secondary pollution offset reduction of primary emissions during COVID-19 lockdown in China. Natl. Sci. Rev. 2020. [CrossRef]

34. Lai, I.-C.; Brimblecombe, P. Long range transport of air pollutants to Taiwan during the COVID-19 lockdown in Hubei Province. Aerosol Air Qual. Res. 2020. [CrossRef]

35. Shi, X.; Brasseur, G.P. Response in air quality to the reduction of Chinese economic activities during the COVID-19 Outbreak. Geophys. Res. Lett. 2020, 47, 1-8. [CrossRef] [PubMed]

36. Chen, Z.; Hao, X.; Zhang, X.; Chen, F. Have traffic restrictions improved air quality? A shock from COVID-19. J. Clean. Prod. 2020, 279, 123622. [CrossRef] [PubMed] 
37. Hannam, P. The Sydney Morning Herald. Virus and Favourable Weather Deliver Clear Skies over Sydney. Available online: https:/ / www.smh.com.au/environment/sustainability/virus-and-favourable-weather-delivers-clear-skies-over-sydney20200422-p54m6z.html (accessed on 1 January 2021).

38. Khaykin, S.; Legras, B.; Bucci, S.; Sellitto, P.; Isaksen, L.; Tencé, F.; Bekki, S.; Bourassa, A.; Rieger, L.; Zawada, D.; et al. The 2019/20 Australian wildfires generated a persistent smoke-charged vortex rising up to $35 \mathrm{~km}$ altitude. Comm. Earth Environ. 2020, 1, 1-12. [CrossRef]

39. Sánchez-García, E.; Leon, J. The Conversation. These 5 Images Show How Air Pollution Changed over Australia's Major Cities before and after Lockdown. Available online: https:/ / theconversation.com/these-5-images-show-how-air-pollution-changedover-australias-major-cities-before-and-after-lockdown-136723 (accessed on 1 January 2021).

40. WessaNet, Version 1.2.1, Free Statistics Software, Wessa, P., Office for Research Development and Education. 2020. Available online: https: / www.wessa.net/ (accessed on 1 January 2021).

41. Silver, B.; He, X.; Arnold, S.R.; Spracklen, D.V. The impact of COVID-19 control measures on air quality in China. Environ. Res. Lett. 2020, 15, 084021. [CrossRef]

42. Brimblecombe, P.; Lai, Y. Diurnal and weekly patterns of primary pollutants in Beijing under COVID-19 restrictions. Faraday Discuss. 2020. [CrossRef]

43. Ulpiani, G.; Ranzi, G.; Santamouris, M. Experimental evidence of the multiple microclimatic impacts of bushfires in affected urban areas: The case of Sydney during the 2019/2020 Australian season. Environ. Res. Commun. 2020, 2, 065005. [CrossRef]

44. Bauwens, M.; Compernolle, S.; Stavrakou, T.; Müller, J.F.; van Gent, J.; Eskes, H.; Levelt, P.F.; van der A, R.; Veefkind, J.P.; Vlietinck, J.; et al. Impact of coronavirus outbreak on NO2 pollution assessed using TROPOMI and OMI observations. Geophys. Res. Lett. 2020, 47, e2020GL087978. [CrossRef]

45. Lamsal, L.N.; Krotkov, N.A.; Vasilkov, A.; Marchenko, S.; Qin, W.; Yang, E.-S.; Fasnacht, Z.; Joiner, J.; Choi, S.; Haffner, D.; et al. OMI/Aura nitrogen dioxide standard product with improved surface and cloud treatments. Atmos. Meas. Tech. Discuss. 2020, 1-56. [CrossRef]

46. Kumar, P.; Hama, S.; Omidvarborna, H.; Sharma, A.; Sahani, J.; Abhijith, K.V.; Debele, S.E.; Zavala-Reyes, J.C.; Barwise, Y.; Tiwari, A. Temporary reduction in fine particulate matter due to 'anthropogenic emissions switch-off'during COVID-19 lockdown in Indian cities. Sustain. Cities Soc. 2020, 62, 102382. [CrossRef] [PubMed]

47. Li, L.; Li, Q.; Huang, L.; Wang, Q.; Zhu, A.; Xu, J.; Liu, Z.; Li, H.; Shi, L.; Li, R.; et al. Air quality changes during the COVID-19 lockdown over the Yangtze River Delta Region: An insight into the impact of human activity pattern changes on air pollution variation. Sci. Total Environ. 2020, 732, 139282. [CrossRef] [PubMed]

48. EPA 2019. Air Emissions Inventory for the Greater Metropolitan Region in New South Wales; EPA 2019P1917; NSW Environment Protection Authority: Sydney, Australia, 2019.

49. Wan, S.; Cui, K.; Wang, Y.-F.; Wu, J.-L.; Huang, W.-S.; Xu, K.; Zhang, J. Impact of the COVID-19 event on trip intensity and air quality in Southern China. Aerosol Air Qual. Res. 2020, 20, 1727-1747. [CrossRef]

50. Brimblecombe, P.; Lai, Y. Effect of sub-urban scale lockdown on air pollution in Beijing. Urban Clim. 2020, 34, 100725. [CrossRef]

51. Scott, K. ABC Life. Surprising Facts about How We Spend Our Time. Available online: https://www.abc.net.au/life/surprisingfacts-about-how-we-spend-our-time/10188202 (accessed on 1 January 2021).

52. Sekar, A.; Jasna, R.S.; Binoy, B.V.; Mohan, P.; Varghese, G.K. Air quality change due to COVID-19 lockdown in India and its perception by public. Res. Square 2020. [CrossRef]

53. Chen, K.; Wang, M.; Huang, C.; Kinney, P.L.; Anastas, P.T. Air pollution reduction and mortality benefit during the COVID-19 outbreak in China. Lancet Planet. Health 2020, 4, e210-e212. [CrossRef]

54. Achebak, H.; Petetin, H.; Quijal-Zamorano, M.; Bowdalo, D.; García-Pando, C.P.; Ballester, J. Reduction in air pollution and attributable mortality due to COVID-19 lockdown. Lancet Planet. Health 2020, 4, e268. [CrossRef]

55. Cori, L.; Bianchi, F. Covid-19 and air pollution: Communicating the results of geographic correlation studies. Epidemiol. Prev. 2020, 44, 120-123.

56. Cicala, S.; Holland, S.P.; Mansur, E.T.; Muller, N.Z.; Yates, A.J. Expected health effects of reduced air pollution from COVID-19 social distancing. In NBER Working Papers 27135; National Bureau of Economic Research, Inc: Cambridge, MA, USA, 2020. [CrossRef]

57. Cartea, P.Á.M. Is there a hole in the ozone layer of your climate change? From scientific culture to popular culture. Mètode Sci. Stud. J. 2016, 6, 57-62.

58. Svatonova, H.; Rybansky, M. Children observe the digital earth from above: How they read aerial and satellite images. IOP Conf. Ser. Earth Environ. Sci. 2014, 18, 012071. [CrossRef]

59. Brimblecombe, P.; Zong, H. Citizen perception of APEC Blue and air pollution management. Atmos. Environ. 2019, $214,116853$. [CrossRef]

60. Brimblecombe, P. A Journal in a Plague Year. City Environ. Interact. 2020, 4, 100028. [CrossRef]

61. Manenti, R.; Mori, E.; Di Canio, V.; Mercurio, S.; Picone, M.; Caffi, M.; Brambilla, M.; Ficetola, G.F.; Rubolini, D. The good, the bad and the ugly of COVID-19 lockdown effects on wildlife conservation: Insights from the first European locked down country. Biol. Conserv. 2020, 249, 108728. [CrossRef] 
62. Geard, N.; Cromer, D. The Conversation. Sydney's Second Wave: Can It Avoid a Melbourne-Style Lockdown? Available online: https:/ / theconversation.com/sydneys-second-wave-can-it-avoid-a-melbourne-style-lockdown-142652 (accessed on 1 January 2021).

63. Barbieri, D.M.; Lou, B.; Passavanti, M.; Hui, C.; Lessa, D.A.; Maharaj, B.; Banerjee, A.; Wang, F.; Chang, K.; Naik, B.; et al. Survey data regarding perceived air quality in Australia, Brazil, China, Ghana, India, Iran, Italy, Norway, South Africa, United States before and during Covid-19 restrictions. Data Brief 2020, 32, 106169. [CrossRef] [PubMed]

64. Tangren, C.D. Scattering coefficient and particulate matter concentration in forest fire smoke. J. Air. Pollut. Control. Assoc. 1982, 32, 729-732. [CrossRef] 